\title{
Seasonal Variation of Carbon and Nitrogen Emissions from Turfgrass
}

\author{
Said A. Hamido ${ }^{*}$, Elizabeth A. Guertal ${ }^{2}$, C. Wesley Wood $^{3}$ \\ ${ }^{1}$ Southwest Florida Research and Education Center, University of Florida, Immokalee, FL, USA \\ ${ }^{2}$ Crop, Soil and Environmental Sciences Department, Auburn University, Auburn, AL, USA \\ ${ }^{3}$ West Florida Research and Education Center, University of Florida, Milton, FL, USA \\ Email: *shamido@ufl.edu,guertea@auburn.edu, woodwes@ufl.edu
}

How to cite this paper: Hamido, S.A., Guertal, E.A. and Wood, C.W. (2016) Seasonal Variation of Carbon and Nitrogen Emissions from Turfgrass. American Journal of Climate Change, 5, 448-463. http://dx.doi.org/10.4236/ajcc.2016.54033

Received: September 12, 2016

Accepted: October 30, 2016

Published: November 2, 2016

Copyright $\odot 2016$ by authors and Scientific Research Publishing Inc. This work is licensed under the Creative Commons Attribution International License (CC BY 4.0).

http://creativecommons.org/licenses/by/4.0/

\section{Abstract}

The role of turfgrasses in $\mathrm{C}$ and $\mathrm{N}$ cycling in the southeastern U.S. has not been well documented. The objectives of this research were to determine the characterization of chemical quality, clipping decomposition rates, and $\mathrm{C}$ and $\mathrm{N}$ release from warmand cool-season turfgrasses. The study was conducted for 46 weeks in 2012 in Auburn, AL. Four warm season turfgrasses were used included (bermudagrass [Cynodon dactylon (L.) Pers. $\times$ C. transvaalensis Burtt Davy], centipedegrass (Eremochloa ophiuroides (Munro) Hack), St. Augustinegrass (Stenotaphrum secundatum (Walter) Kuntze), zoysiagrass (Zoysia japonica Steud.), and one cool season turfgrass (tall fescue (Festuca arundinacea Schreb)). Litter was placed into nylon bags at an oven

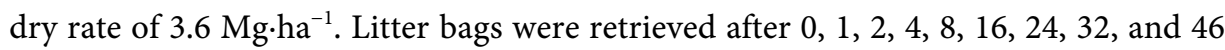
weeks, and analyzed for total $\mathrm{C}$ and $\mathrm{N}$. A double exponential decay model was used to describe mass, $\mathrm{C}$, and $\mathrm{N}$ loss. Results indicated that tall fescue decomposition occurred rapidly compared to warm season turfgrasses. Litter mass loss measured after 46 weeks was determined to be $61.7 \%, 73.7 \%, 72.2 \%, 86.8 \%$, and $45.4 \%$ in bermudagrass, centipedegrass, St. Augustinegrass, tall fescue, and zoysiagrass respectively. Zoysiagrass litter had a higher lignin concentration, while tall fescue had the lowest lignin. Over 46 weeks' release of $\mathrm{C}$ was in the order: zoysiagrass $>$ bermudagrass $=$ centipedegrass $=$ St. Augustinegrass $>$ tall fescue, and release of $\mathrm{N}$ was in the order zoysiagrass $>$ centipedegrass $>$ bermudagrass $=$ St. Augustinegrass $>$ tall fescue. Our study concluded that, zosiagrass is a better choice for home lawns.

\section{Keywords}

Double-Exponential Decay Model, Turfgrasses, Fiber Content 


\section{Introduction}

Understanding litter decomposition process in a given ecosystem is vital due to its effect on greenhouse gas concentration and biogeochemical cycling in terrestrial ecosystems. During decomposition, significant amounts of greenhouse gases, including $\mathrm{CO}_{2}$, $\mathrm{CH}_{4}$, and $\mathrm{N}_{2} \mathrm{O}$, are released [1]. Plants may also play an important role in $\mathrm{C}$ and nutrient cycling through the quality and quantity of their residues [2] [3] [4]. Also, the quality and type of litter material influence soil organic matter content [5].

Organic matter with higher C:N or lignin: $\mathrm{N}$ ratios decomposes slower, a function of lower $\mathrm{N}$ mineralization rates and increased $\mathrm{N}$ immobilization in microbial biomass [6]. Moreover, the ability of soil microorganisms to decompose and/or mineralize organic matter depends on the chemical structure of the $\mathrm{C}$ compounds [7]. Complex C compounds such as lignin can retard litter decomposition. Thus, the composition of plant residues, in particular $\mathrm{C}, \mathrm{N}$, and lignin concentrations, determines the rate and extent of decomposition of such residues. The concentration of lignin alone or the lignin: $\mathrm{N}$ content can be used as an indicator of decomposition rates [8] [9] [10].

Litter decomposition pattern of any material can be divided into two phases: an early and a later stage which are regulated by fractions different chemical of the material. The early phase is regulated by the labile fraction including sugars, starch, soluble and unprotected cellulose and hemicelluloses [11] and the later phase is regulated by the recalcitrant fraction including lignin and cellulose [12]. Thus, lignin and cellulose become dominant in the residue [13]. In some cases, the rate of decomposition approaches zero. This second portion is slowly decomposed, contributing to the development of soil organic matter.

There is limited research which examines decomposition rate of $\mathrm{C}$ and $\mathrm{N}$ dynamics in the long-term, non-tilled conditions in which warm and cool season's turfgrasses are grown. There is a need to evaluate $\mathrm{C}$ and $\mathrm{N}$ dynamics in warm and cool season's turfgrasses in the southeast United States. The objectives of this research were to determine the characterization of chemical quality, clipping decomposition rates, and $\mathrm{C}$ and $\mathrm{N}$ release from warm- and cool-season turfgrasses. That will solidify our understanding of different turfgrasses dynamics under current environment. In addition, it will reduce the emission of greenhouse gases through altering current turfgrass management by lowering fertilizer application rates and timing. A recent study summarized net $\mathrm{C}$ sequestration in home lawn turfgrasses across the U.S. included some warmseason turfgrasses, a large-scale survey from 16 sites across the U.S. [14]. However, there are no studies which examine decomposition as a function of specific warmseason turfgrass species, which have different growth patterns from cool-season turfgrasses. Thus, the objectives of this study were to assess mass loss and $\mathrm{C}$ and $\mathrm{N}$ decomposition rates from warm (bermudagrass, centipedegrass, St. Augustinegrass, and zoysiagrass) and cool (tall fescue) seasons turfgrass clippings and exploring the relationships between chemical leaf composition, particularly fiber content, and decomposition rates and $\mathrm{C}$ and $\mathrm{N}$ release under field conditions. The reason behind choosing these grasses is their extensive use in urban eco-systems in the southeastern U.S. 


\section{Materials and Methods}

\subsection{Site Description and Sampling}

A field decomposition study was initiated in May 17, 2012 and conducted for 46 weeks (wk) at the Auburn University Turfgrass Research Unit $\left(32.58^{\circ} \mathrm{N}, 85.50^{\circ} \mathrm{W}\right)$, Auburn, AL, USA, on a Marvyn loamy sand soil (fine-loamy, kaolinitic, thermic Typic Kanhapludult). The mean annual air and soil temperatures were $17^{\circ} \mathrm{C}$ and $19^{\circ} \mathrm{C}$, respectively and the mean annual precipitation was $1233 \mathrm{~mm}$ (2011-2014, AWIS, 2014). Experiments were installed in 5 existing areas of common southeaster turfgrasses (4 warm season and 1 cool season): bermudagrass [Cynodon dactylon (L.) Pres. $\times$ Cynodon transvaalensis Burtt. Davy cv "Tifway"], Centipedegrass (Eremochloa ophiuroides Munro Hack cv "common"), St. Augustinegrass (Stenotaphrum secundatum Walter Kuntze cv "Floratam"), and zoysiagrass (Zoysia japonica Steud.) cv "Meyer", and cool seasontall fescue (Festuca arundinacea Schreb) cv "Rebel Exeda" were the selected species and cultivars. All of the turfgrass stands had been established for at least 5 years, and none were older than 7 years. All plots areas were no more than $300 \mathrm{~m}$ from each other. Swards were managed as lawn grasses, with the following mowing heights for each: bermudagrass and zoysiagrass $(5.0 \mathrm{~cm})$, tall fescue and St. Augustinegrass $(7.6 \mathrm{~cm})$ and centipedegrass $(6.4 \mathrm{~cm})$. Plots were mown either with a walk behind homeowner-type reel mower (Tru-Cut Mowers, Inc., 141 East 157th Street, Gardena, CA 90248) (bermudagrass and zoysiagrass) or with a homeowner riding rotary mower (Husqvarna Professional Products, Inc. Charlotte, NC 28269) (all other grasses), respectively. All plots were mown three days a week with clippings returned. Supplemental irrigation was provided in the absence of rainfall so that irrigation + precipitation equaled 2.5 $\mathrm{cm} \cdot \mathrm{wk}^{-1}$. An on-site weather station was used to determine daily precipitation.

A litter bag decomposition method, often used in forestry, was employed for this study [15] [16]. For litter collection, all turfgrasses were harvested ( $3 \mathrm{~m}$ wide $\times 3 \mathrm{~m}$ long plot) at a height to remove no-more than $1 / 3$ of uppermost green leaf tissue, for each respective mowing height. This ensured that scalping did not occur and that the majority of tissue was comprised of fresh leaf growth. All tissue was harvested using the mower that was used for plot maintenance, and clippings were collected in attached baskets. Four replicate plots of each turfgrass were harvested, and each was tracked through a litter bag as a replicate plot at each harvest time. Litter was transported immediately to the laboratory. Litter of each grass from each replicate was mixed separately, and weeds or other debris were removed. Litter was placed into nylon bags (ANKOM technology, Macedon, NY) measuring $10 \times 20 \mathrm{~cm}$ with 50 to $60 \mu \mathrm{m}$ openings at a rate of $30 \mathrm{~g}$ oven dry $\cdot \mathrm{bag}^{-1}\left(3.6 \mathrm{Mg} \cdot \mathrm{ha}^{-1}\right)$. The bags (total of 180 ; four replicates for each species) were incubated in the field, placed directly into the thatch layer (the area had been trimmed free of verdure) on the same grass plots from where it was harvested. The bags were anchored with sod staples at the edge of each bag, ensuring that the bags would not move due to wind or predators. Spacing between individual bags was $30 \times 45$ $\mathrm{cm}$ to prevent any interactions among bags. The total incubation period was $46 \mathrm{wk}$ 
(from May 17, 2012 to April 4, 2013). Four bags (replicates) of each species were retrieved at $1,2,4,8,16,24,32$, and $46 \mathrm{wk}$. Fertilizer was withheld from experimental plots during the experiment.

Soil moisture and temperature were measured on a weekly basis using an auxiliary sensor (Onset Computer Corporation, 470 MacArthur Blvd., Bourne, MA 02532). The sensor was placed at a $5.0 \mathrm{~cm}$ depth in the soil, with soil moisture and temperature recorded at 5 minute intervals. Three sensors were placed in the bermudagrass plot area and results averaged for use for all grasses. Spot checks throughout the study period revealed that soil moisture and temperature was not substantially affected (over the entire study period) by grass species.

\subsection{Carbon and Nitrogen Analyses}

The four replicate bags from each grass species were retrieved from the field at $0,1,2,4$, $8,16,24,32$, and $46 \mathrm{wk}$. Retrieved bags were emptied into plastic containers and oven-dried at $55^{\circ} \mathrm{C}$ for $72 \mathrm{~h}$ and weighed for dry-matter determination. Litter was ground to pass a $1 \mathrm{~mm}$-sieve and analyzed for total $\mathrm{C}$ and $\mathrm{N}$ using LECO TruSpec CN analyzer (Leco Corp, St. Joseph, MI). All data were converted to an ash-free dry weight basis by ashing $1 \mathrm{~g}$ of sample in a muffle furnace at $450^{\circ} \mathrm{C}$ for 16 hours [17]. In addition, $\mathrm{C}: \mathrm{N}$ ratios were calculated.

\subsection{Initial Fiber Analysis}

Initial values of lignin concentration in leaf litter were assessed by the acid-detergent digestion technique [18]. The acid detergent fiber technique measures cellulose, lignin, and ash, and represents the insoluble components of cell walls. Acid detergent lignin $(\mathrm{ADL})$ is an estimate of the lignin content. Neutral detergent fiber (NDF) comprises the insoluble components of cell walls (cellulose, hemicellulose, and lignin). Acid detergent fiber $(\mathrm{ADF})$ is a measure of cellulose and lignin [19].

\subsection{Decay Model}

A double, four-parameter exponential decay model (Equation (1)) [13] [20], simulating decomposers and substrates (labile and the recalcitrant constants) dynamics in grasslands, was used to describe the decay pattern.

$$
Y=A e^{-b x}+C e^{-d x}
$$

where $Y=$ remaining mass (normalized \%),

$A=$ the labile portion,

$C=$ the recalcitrant portion,

$b$ and $d$ are the labile and the recalcitrant constants, respectively, and

$x=$ time in weeks.

\subsection{Data Analysis}

Means, standard errors, and statistical variations of treatments were determined using mixed models procedures [21]. Least squares estimates for nonlinear models were de- 
termined using four parameter double exponential decay models [22]. Double exponential decay models were employed as the basis for comparison of mass, $\mathrm{N}$, and C loss between dates among all grasses. SigmPlot 12.1, Non-Linear Regression, was used to identify correlations ( $r$ ) among variables [22].

\section{Results and Discussion}

\subsection{Initial Fiber Analysis}

The initial fiber composition of harvested clippings had significant variation among the five turfgrass species (Table 1). For example, St. Augustinegrass clippings were significantly higher in acid detergent fiber (cellulose + lignin) (ADF) and ash contents than bermudagrass, centipedegrass, tall fescue, and zoysiagrass. Zoysiagrass litter had significantly higher lignin concentration, $6 \% \pm 0.3 \%$ (mean $\pm \mathrm{SE}$ ), while tall fescue had the lowest content, at $3 \% \pm 0.3 \%$. The initial harvest of bermudagrass clippings had significantly higher neutral detergent fiber (hemicellulose + cellulose + lignin) (NDF) than found in other grasses, measuring $85 \% \pm 0.3 \%$. In contrast, tall fescue had the lowest NDF, measured at $63 \% \pm 1.1 \%$. Fiber contents play an important role in accelerating and/or suppressing decomposition processes.

The litter exhibiting higher initial lignin content had slower decomposition rates. For example, decomposition of Quercus dealbata (6\% lignin) litter had slower decomposition than Quercus fenestrata (4\% lignin) [23]. In other work, concentration of the lignin fraction increased as decomposition proceeded [24], and litter was enriched with lignin [25]. In later stages of decomposition, recalcitrant substances become more dominant in the residue, and in some cases the rate of decomposition approaches zero.

\subsection{Remaining Mass}

In all cases, the decay models were significant $(P<0.0001)$ with reasonably high adjusted $\mathrm{R}^{2}$ values (Table 2). All data were expressed on a normalized basis (percent remaining) (Figure 1). Figure 1 indicates that the litter mass loss measured after 46 weeks was estimated at $45.4 \%, 61.7 \%, 73.7 \%, 72.2 \%$, and $86.8 \%$ in zoysiagrass, bermudagrass,

Table 1. Initial turfgrasses clipping contents $\left(\mathrm{g} \cdot \mathrm{kg}^{-1}\right)$ and the carbon and nitrogen (\%) released after 46 weeks of field incubation

\begin{tabular}{cccccccc}
\hline \multirow{2}{*}{ Grasses } & \multicolumn{4}{c}{ Initial contents $\left(\mathrm{g}^{\mathrm{kg}} \mathrm{kg}^{-1}\right)$} & \multicolumn{3}{c}{ Released contents (\%) } \\
\cline { 2 - 8 } & NDF & ADF & ADL & Carbon & Nitrogen & Carbon & Nitrogen \\
\hline Bermuda & $849.60 \mathrm{a}$ & $347.61 \mathrm{~b}$ & $49.00 \mathrm{~b}$ & $396 \mathrm{a}$ & $23.0 \mathrm{~b}$ & $63.3 \mathrm{c}$ & $53.6 \mathrm{~b}$ \\
Centipede & $731.66 \mathrm{~d}$ & $356.37 \mathrm{~b}$ & $39.43 \mathrm{c}$ & $421 \mathrm{a}$ & $14.5 \mathrm{c}$ & $66.2 \mathrm{c}$ & $37.3 \mathrm{c}$ \\
St. Augustine & $800.85 \mathrm{c}$ & $424.65 \mathrm{a}$ & $48.80 \mathrm{~b}$ & $340 \mathrm{~b}$ & $14.7 \mathrm{c}$ & $82.1 \mathrm{~b}$ & $85.8 \mathrm{a}$ \\
Tall fescue & $629.34 \mathrm{e}$ & $296.17 \mathrm{c}$ & $31.33 \mathrm{c}$ & $412 \mathrm{a}$ & $40.0 \mathrm{a}$ & $87.9 \mathrm{a}$ & $87.7 \mathrm{a}$ \\
Zoysia & $824.54 \mathrm{~b}$ & $371.19 \mathrm{~d}$ & $59.61 \mathrm{a}$ & $429 \mathrm{a}$ & $14.6 \mathrm{c}$ & $45.1 \mathrm{~d}$ & $31.5 \mathrm{c}$ \\
\hline
\end{tabular}

Means in the same column with the same letter are not significantly different at $\alpha \leq 0.05$; NDF $=$ Natural Detergent Fiber contains hemicellulose + cellulose + lignin (approximately total cell wall), ADF $=$ Acid Detergent Fiber comprise cellulose + lignin, and $\mathrm{ADL}=$ Acid Detergent Lignin . 


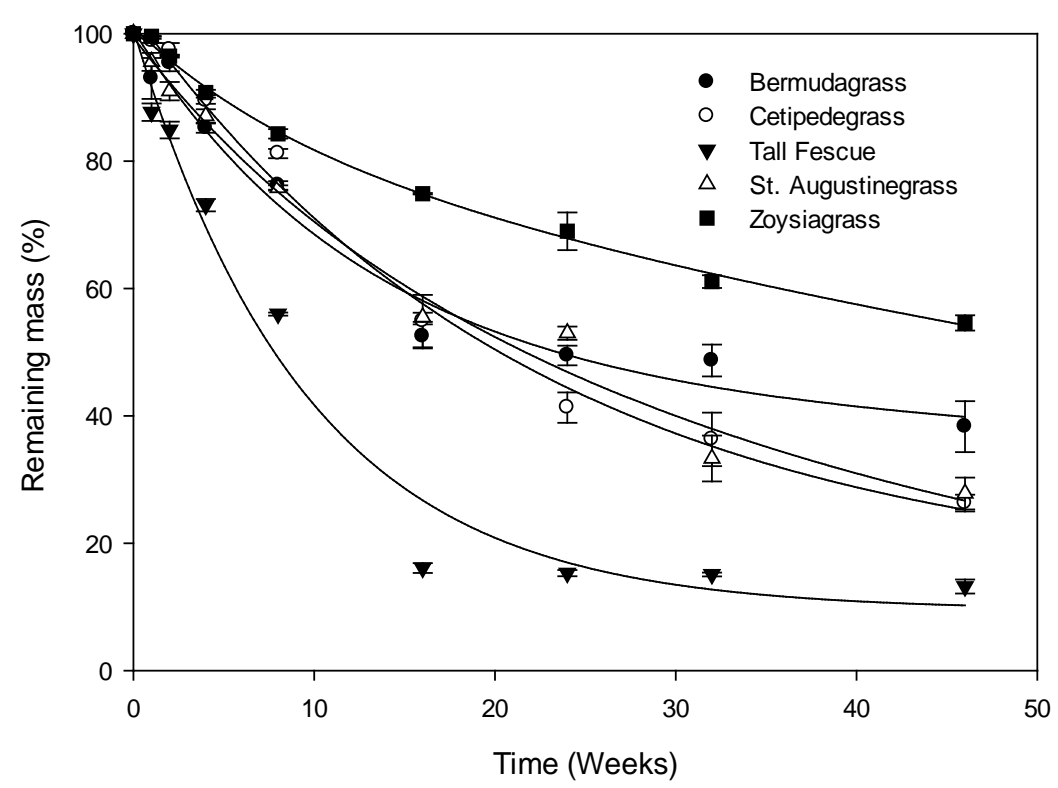

Figure 1. Mass loss from turfgrass clippings over time, Auburn University Turfgrass Research Unit, 2012-2013. Lines represent fitted curves for each grass describing decay pattern over time. Error bars represent standard error about the mean.

Table 2. Double exponential decay equations regressed on time (weeks) for mass, C, and N-loss from turfgrass incubated in litter bags under field conditions. Double exponential decay equations are in the form of $\mathrm{Y}=\mathrm{Ae}^{-b x}+\mathrm{Ce}^{-d x}$, where $\mathrm{Y}=$ remaining mass (normalized \%), $\mathrm{A}=$ the labile portion, $\mathrm{C}=$ the portion, $b$ and $d$ are the labile and the recalcitrant constants, respectively, and $\mathrm{x}=$ time in weeks.

\begin{tabular}{ccccc}
\hline Turfgrass & Equation & $\mathbf{P}>\mathbf{F}^{\dagger}$ & $\mathbf{R}_{\text {adj }}^{2}$ & Syx $^{\ddagger}$ \\
\hline Mass & $\mathrm{Y}=56.22 \mathrm{e}^{-0.08 \mathrm{x}}+44.33 \mathrm{e}^{-0.003 \mathrm{x}}$ & $<0.0001$ & 0.99 & 1.14 \\
Bermudagrass & $\mathrm{Y}=89.54 \mathrm{e}^{-0.05 \mathrm{x}}+13.75 \mathrm{e}^{-8.28 \mathrm{E}-19 \mathrm{x}}$ & $<0.0001$ & 0.97 & 5.24 \\
Centipedegrass & $\mathrm{Y}=19.43 \mathrm{e}^{-0.09 \mathrm{x}}+80.02 \mathrm{e}^{-0.02 \mathrm{x}}$ & $<0.0001$ & 0.96 & 4.69 \\
St. Augustinegrass & $\mathrm{Y}=91.25 \mathrm{e}^{-0.11 \mathrm{x}}+9.47 \mathrm{e}^{-8.12 \mathrm{E}-19 \mathrm{x}}$ & $<0.0001$ & 0.96 & 4.69 \\
Tall Fescue & $\mathrm{Y}=16.87 \mathrm{e}^{-0.12 \mathrm{x}}+84.14 \mathrm{e}^{-0.01 \mathrm{x}}$ & $<0.0001$ & 0.96 & 4.69 \\
Zoysiagrass & & & & \\
Carbon & $\mathrm{Y}=47.61 \mathrm{e}^{-0.11 \mathrm{x}}+52.13 \mathrm{e}^{-0.01 \mathrm{x}}$ & $<0.0001$ & 0.99 & 2.46 \\
Bermudagrass & $\mathrm{Y}=87.82 \mathrm{e}^{-0.04 \mathrm{x}}+13.72 \mathrm{e}^{-4.93 \mathrm{E}-18 \mathrm{x}}$ & $<0.0001$ & 0.98 & 3.14 \\
Centipedegrass & $\mathrm{Y}=87.67 \mathrm{e}^{-0.04 \mathrm{x}}+5.21 \mathrm{e}^{-9.92 \mathrm{E}-18 \mathrm{x}}$ & $<0.0001$ & 0.96 & 4.69 \\
St. Augustinegrass & $\mathrm{Y}=89.91 \mathrm{e}^{-0.11 \mathrm{x}}+9.32 \mathrm{e}^{-1.08 \mathrm{E}-17 \mathrm{x}}$ & $<0.0001$ & 0.97 & 6.04 \\
Tall Fescue & $\mathrm{Y}=11.17 \mathrm{e}^{-0.28 \mathrm{x}}+90.14 \mathrm{e}^{-0.01 \mathrm{x}}$ & $<0.0001$ & 0.98 & 2.06 \\
Zoysiagrass & & & & \\
Nitrogen & $\mathrm{Y}=30.15 \mathrm{e}^{-0.28 \mathrm{x}}+69.82 \mathrm{e}^{-0.01 \mathrm{x}}$ & $<0.0001$ & 0.98 & 2.97 \\
Bermudagrass & $\mathrm{Y}=8.64 \mathrm{e}^{-0.89 \mathrm{x}}+91.36 \mathrm{e}^{-0.01 \mathrm{x}}$ & $<0.0001$ & 0.97 & 2.54 \\
Centipedegrass & $\mathrm{Y}=28.58 \mathrm{e}^{-0.56 \mathrm{x}}+72.31 \mathrm{e}^{-0.02 \mathrm{x}}$ & 0.0002 & 0.95 & 4.70 \\
St. Augustinegrass & $\mathrm{Y}=72.26 \mathrm{e}^{-0.21 \mathrm{x}}+22.68 \mathrm{e}^{-0.01 \mathrm{x}}$ & 0.0001 & 0.96 & 5.71 \\
Tall Fescue & $\mathrm{Y}=20.49 \mathrm{e}^{-0.16 \mathrm{x}}+79.94 \mathrm{e}^{-3.62 \mathrm{E}-19 \mathrm{x}}$ & 0.0290 & 0.69 & 4.95 \\
Zoysiagrass & & &
\end{tabular}

${ }^{\dagger}$ Significance of fit. ${ }^{*}$ Standard error of the estimate. 
centipedegrass, St. Augustinegrass, and tall fescue, respectively. However, zoysiagrass had very slow decomposition, with only $25 \%$ loss from an initial equivalent of $360 \mathrm{~g} \cdot \mathrm{m}^{-2}$ to $270 \mathrm{~g} \cdot \mathrm{m}^{-2}$. Similar results were observed by [26]. They found that, in 16 weeks' decomposition study, combinations of litters of cool-season turfgrass clippings of a bluegrass-ryegrass-red fescue mixture decomposed rapidly during the first 4 months, with a value of $\approx 70 \%$ of total mass [26]. The faster decomposition rate of tall fescue can be partially explained by the lower initial ADF content.

The labile decay constant of zoysiagrass residue value (0.12) was 2.6 times greater than that of centipede grass (0.05) but closer to that of tall fescue (0.10). The effects of grass species on decay of recalcitrant portions were more distinct. The recalcitrant decay constant of zoysiagrass $(0.0096)$ was greater than that of centipedegrass $(8.28 \times$ $\left.10^{-19}\right)$ or tall fescue $\left(8.12 \times 10^{-19}\right)$. Rapid decay of turfgrass tissues are typically related to warmer soil temperatures (Figure 2) [27]-[32] and adequate moisture contents [32] [33] [34], which stimulate both soil microbial activity and arthropods involved in decomposition processes.

Labile portions of warm-season turfgrass litter increased from $16.9 \%$ to $89.5 \%$, and recalcitrant portions decreased from $84.1 \%$ to $13.8 \%$ under zoysiagrass and centipedegrass, respectively (Table 2). In contrast, tall fescue (cool-season grass) had a labile portion of $91.2 \%$, and a recalcitrant portion of $9.5 \%$. Such contents could significantly influence decomposition processes by acceleration and/or suppression. Thus, increasing the labile fraction is associated with decreasing the recalcitrant portion and will increase the decomposition rate.

\subsection{Carbon Release from Turfgrass Clippings}

All C data were expressed on a normalized basis (percent remaining) (Figure 3). In all cases, the regression models were significant $(P<0.0001)$ with reasonably high adjusted

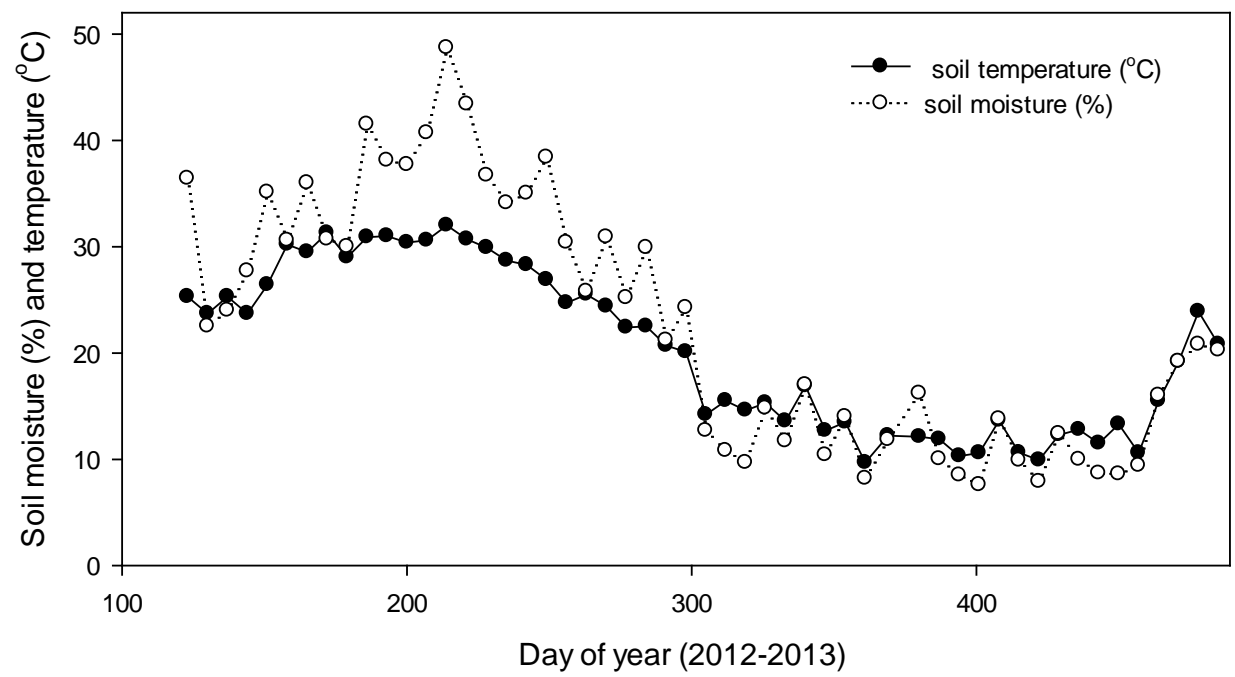

Figure 2. Measured soil temperature and moisture contents at $5 \mathrm{~cm}$ soil depth during decomposition study at the Auburn University Turfgrass Research Unit, 2012-2013. 


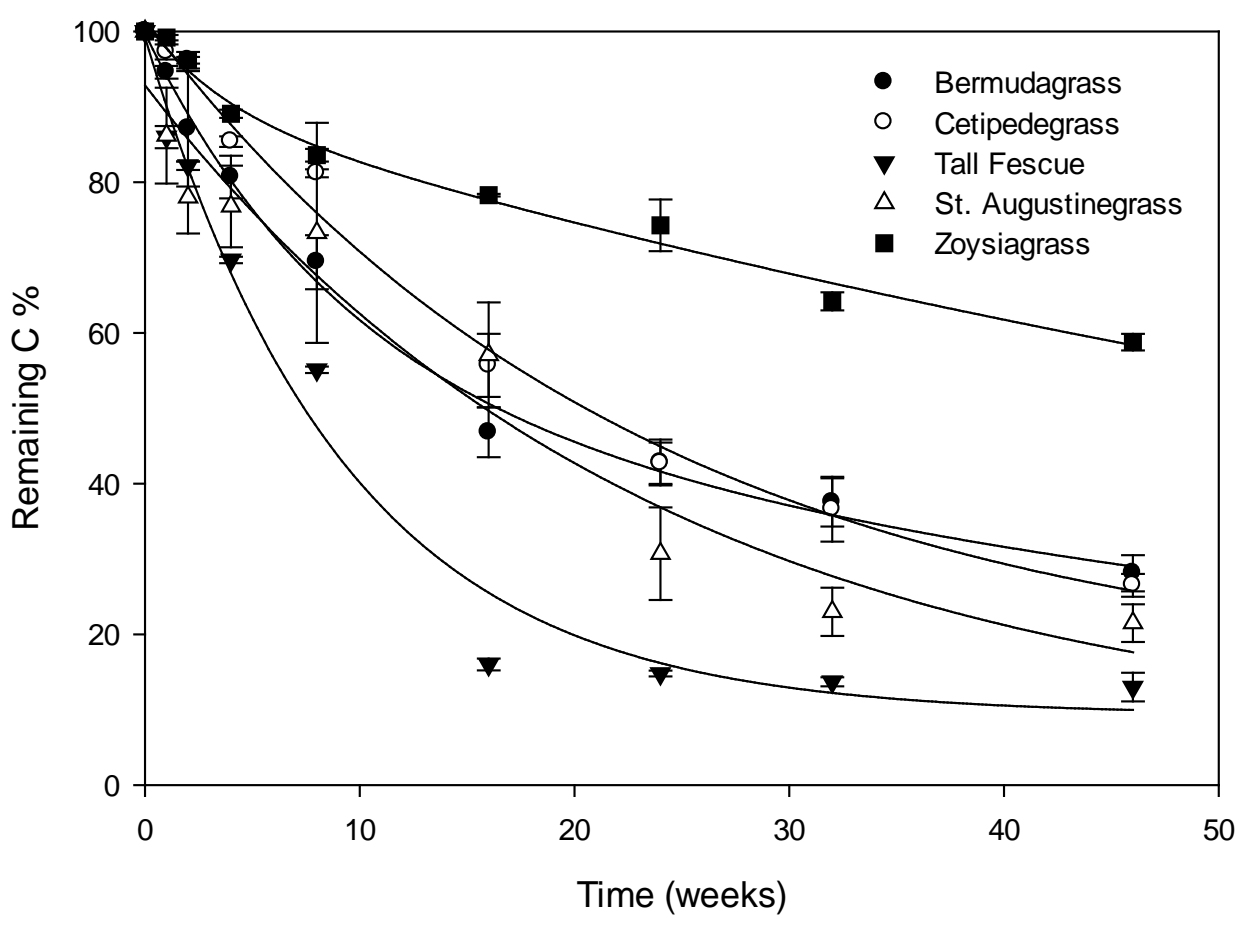

Figure 3. Carbon loss from turfgrass clippings, Auburn University Turfgrass Research Unit, 2012-2013. Lines represent fitted curves for each grass describing decay pattern over time. Error bars represent standard error about the mean.

$\mathrm{R}^{2}$ values (Table 2). As with the mass models, the $\mathrm{C}$ rate constant values $c$ and $d$ were larger for zoysiagrass residue than for centipedegrass, St. Augustinegrass, and tall fescue residues combined. Initial C concentrations of turfgrasses differed slightly, from $42.8 \%$ in zoysiagrass, compared to 40.6, 42.2, 41.7, and 39.1 under bermudagrass, centipedegrass, tall fescue, and St. Augustinegrass, respectively. After 16 weeks of field incubation, zoysiagrass had lost only $21.7 \%$ of $\mathrm{C}$ content, while tall fescue lost $84 \%$. Carbon loss models were comparable to mass loss. This loss was attributed to mass lost through microbial respiration of $\mathrm{C}\left(\right.$ as $\left.\mathrm{CO}_{2}\right)$ to the atmosphere [35]. Tall fescue $\mathrm{C}$ decreased faster during warmer temperatures. The labile decay constant of tall fescue value (0.11) (Table 2) was greater than that of centipede and St. Augustine grasses combined. The recalcitrant decay constant of tall fescue $\left(1.07 \times 10^{-17}\right)$ was nearly two times greater than centipedegrass $\left(4.93 \times 10^{-18}\right)$ and more than 100 times lower than zoysiagrass $(0.01)$. The labile $\mathrm{C}$ portion of centipedegrass, tall fescue, and St. Augustinegrass was greater than $87 \%$, and the recalcitrant portion of all these grasses was lower than $14 \%$. In comparison, zoysiagrass had approximately $11 \%$ labile and $90 \%$ recalcitrant fractions. This may be the reason behind resistance to decay.

The time to decompose the turfgrass clipping varied with species. At 24 weeks, tall fescue $\mathrm{C}$ had declined by $85.2 \%$, while zoysiagrass decreased by $25.7 \%$. These differences may be caused by the chemical fiber structure such as NDF in the clippings. After 46 weeks, there were significant differences in $\mathrm{C}$ among turfgrass clippings with exception of bermudagrass and centipedegrass. 
Carbon concentrations were negatively correlated with sampling time in bermudagrass $\left(r=0.88^{* *}\right)$ and St. Augustinegrass $\left(r=0.72^{\star}\right)$, however, correlation was positive for centipedegrass $\left(r=0.85^{\star *}\right)$, tall fescue $\left(r=0.91^{\star * *}\right)$, and zoysiagrass $\left(r=0.75^{\star}\right)$ (Figure 4). The increase or decrease of $\mathrm{C}$ over time could be related to microbial biomass decomposition causing $\mathrm{C}$ release from soil or immobilization by microbial population.

\subsection{Nitrogen Release from Turfgrass Clippings}

Nitrogen data fit to double exponential decay models on a normalized basis. Adjusted $\mathrm{R}^{2}$ value for that model was high, with the exception of that calculated for zoysiagrass (0.69). This was likely due to the small amount of $\mathrm{N}$ and fast release of labile $\mathrm{N}$ for zoysiagrass. Initial $\mathrm{N}$ concentrations in turfgrasses were low, with a $\mathrm{N}$ concentration of $14.5 \mathrm{~g} \cdot \mathrm{N} \cdot \mathrm{kg}^{-1}$ in centipedegrass, compared to 14.7 and $14.6 \mathrm{~g} \cdot \mathrm{kg}^{-1}$ in St. Augustinegrass and zoysiagrass, respectively. Tall fescue had a higher $\mathrm{N}$ concentration (40 g. $\mathrm{kg}^{-1}$, Table 3 ), followed by bermudagrass ( $\left.23 \mathrm{~g} \cdot \mathrm{kg}^{-1}\right)$. After 24 weeks of field incubation, zoysiagrass lost $17.3 \%$ of $\mathrm{N}$ content, compared to $47.4 \%, 31.1 \%, 49.5 \%$, and $83.6 \%$ loss by bermudagrass, centipedegrass, St. Augustinegrass, and tall fescue, respectively (Figure 5).

The labile decay constant of centipedegrass ( 0.88 ; Table 2$)$ was greater than that of bermudagrass, tall fescue, and zoysiagrass combined. The recalcitrant decay constant of centipede (0.01) was not greater than that of tall fescue (0.01) and more than 100 times greater than zoysiagrass $\left(3.62 \times 10^{-19}\right)$. The higher the constant the faster the decomposition.

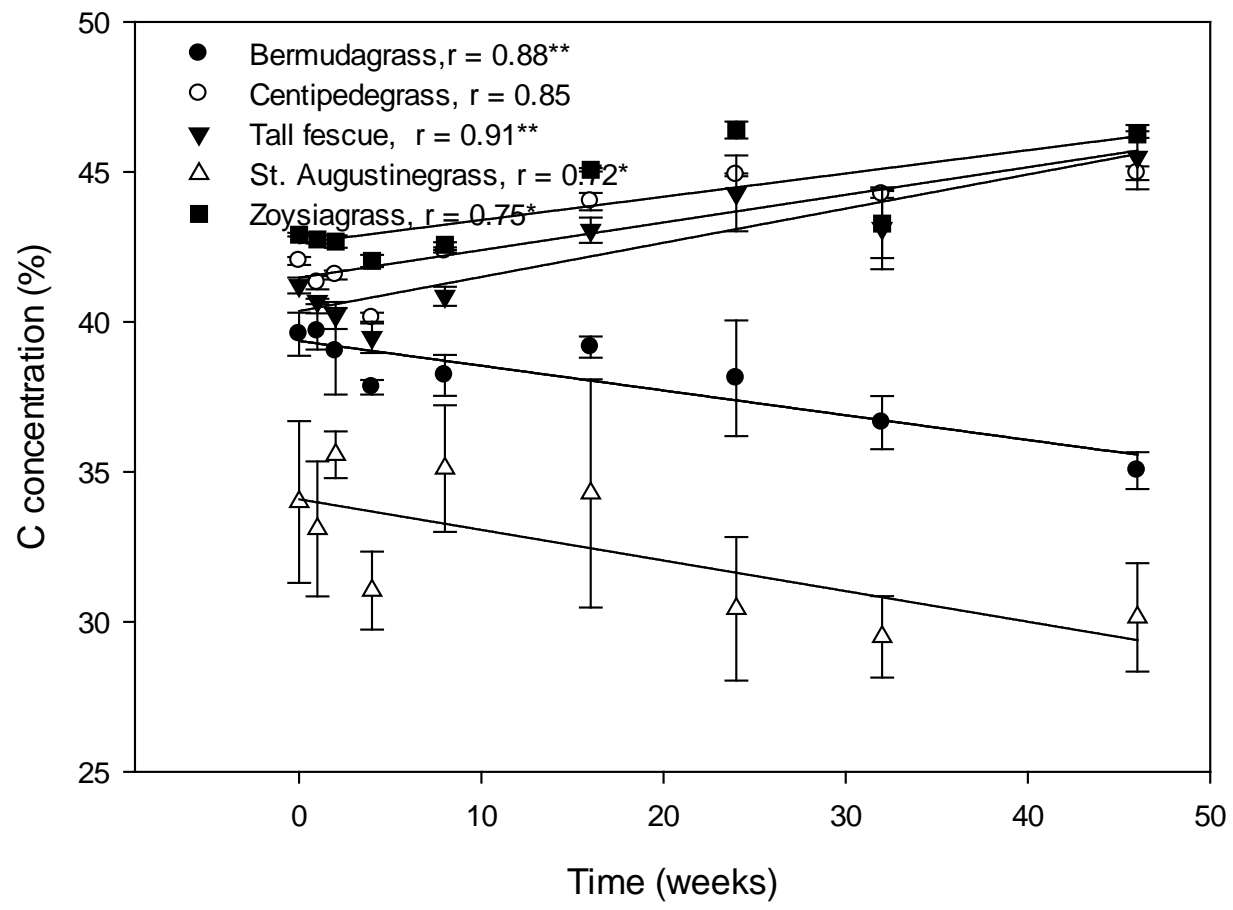

Figure 4. Relationship between C concentration (\%) and time of sampling for turfgrass clippings, Auburn University Turfgrass Research Unit, 2012-2013. Lines represent fitted curves for C\% content of each grass. 


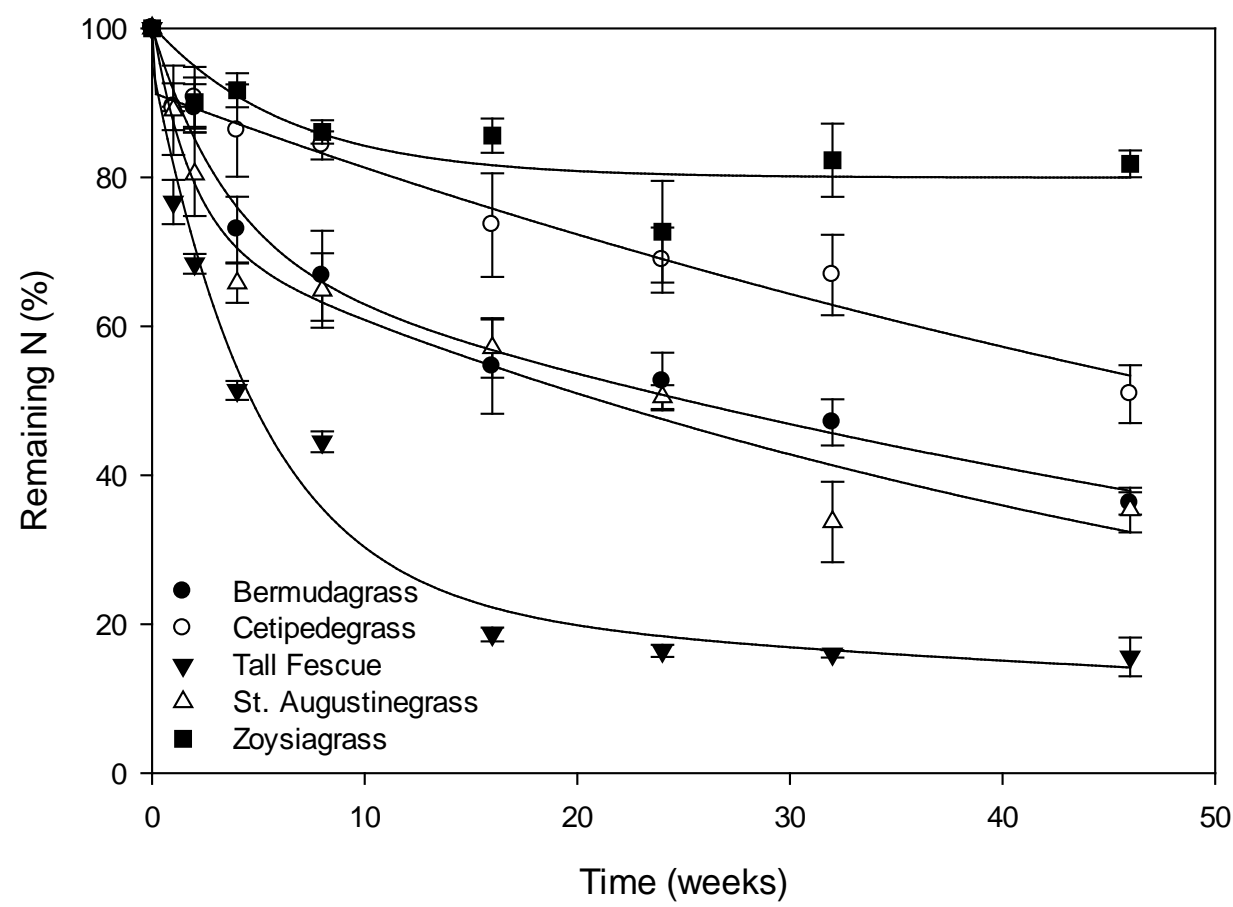

Figure 5. Nitrogen loss from turfgrass clippings, Auburn University Turfgrass Research Unit, 2012-2013. Lines represent fitted curves for each grass describing decay pattern over time. Error bars represent standard error about the mean.

Table 3. Carbon: nitrogenratios \pm S.E of turfgrasses at each sampling period.

\begin{tabular}{cccccc}
\hline Week & Bermuda grass & Centipede grass & Tall fescue & St. Augustine grass & Zoysia grass \\
\hline 0 & $18.6 \pm 0.7$ & $28.7 \pm 1.0$ & $10.3 \pm 0.1$ & $22.4 \pm 1.3$ & $29.3 \pm 0.7$ \\
1 & $19.4 \pm 0.3$ & $29.1 \pm 0.8$ & $11.6 \pm 0.3$ & $22.2 \pm 2.5$ & $28.3 \pm 0.5$ \\
2 & $19.9 \pm 0.4$ & $30.5 \pm 1.3$ & $12.4 \pm 0.2$ & $23.2 \pm 0.9$ & $30.5 \pm 0.6$ \\
4 & $20.6 \pm 0.5$ & $28.7 \pm 1.4$ & $14.0 \pm 0.4$ & $24.7 \pm 1.0$ & $28.6 \pm 1.1$ \\
8 & $19.4 \pm 0.3$ & $26.5 \pm 0.5$ & $12.8 \pm 0.5$ & $18.3 \pm 5.5$ & $28.3 \pm 0.6$ \\
16 & $16.1 \pm 0.9$ & $22.1 \pm 0.5$ & $8.9 \pm 0.1$ & $21.7 \pm 1.7$ & $26.8 \pm 0.5$ \\
24 & $15.1 \pm 0.4$ & $17.8 \pm 0.7$ & $9.4 \pm 0.4$ & $16.4 \pm 0.8$ & $26.1 \pm 1.1$ \\
32 & $14.7 \pm 0.2$ & $15.5 \pm 0.4$ & $8.8 \pm 0.4$ & $14.7 \pm 0.3$ & $23.6 \pm 0.4$ \\
46 & $14.3 \pm 0.5$ & $15.0 \pm 0.2$ & $9.6 \pm 0.6$ & $13.4 \pm 0.3$ & $20.5 \pm 0.3$ \\
\hline
\end{tabular}

The labile portion of tall fescue was $72 \%$, and the recalcitrant portion was $23 \%$ (Table 2). McCurdy et al. [36] found similar results, with a labile fraction of $80 \%$ and a recalcitrant portion of $25 \%$ in white clover litter incubated under field conditions. In contrast, centipedegrass had a low labile fraction (9\%) and a high recalcitrant fraction (91\%), indicating slower decomposition rate.

After 46 weeks, statistical analysis shows significant differences in the remaining and released $\mathrm{N}$ concentration among turfgrasses. For example, zoysiagrass represented the lowest value of released $\mathrm{N}$ with a value of $31.5 \%$ of total $\mathrm{N}$ compared to $87.7 \%$ of released $\mathrm{N}$ from tall fescue (Table 3 ). 
Although the biomass of all grasses are decreasing over time, the $\mathrm{N}$ concentration is increasing (Figure 6). Nitrogen concentrations were significantly correlated with sampling time in bermudagrass $\left(r=0.86^{* *}\right)$, centipedegrass $\left(r=0.98^{\star *}\right)$, tall fescue $(r=$ $\left.0.77^{\star}\right)$, St. Augustinegrass $\left(\mathrm{r}=0.94^{* *}\right)$, and zoysiagrass $\left(\mathrm{r}=0.96^{* *}\right)$ (Figure 6). A linear relationship between percent remaining biomass and nutrient concentration has been noted in other plants [37] [38] [39]. Changes in mass indicate loss of organic C during respiration, while changes in $\mathrm{N}$ concentration indicate changes in microbial biomass [37].

Previous studies reported similar results under different ecosystems, included five exotic plant species such as Acacia auriculiformis, Cassia siamea, Casuarina equisetifolia, Eucalyptus hybrid and Grevillea pteridifolia growing on coal mine spoil [40], in pine needles [41], woodland ecosystems [42] and a mixture of herbaceous plants in Mediterranean subtropical agro-ecosystems [43]. This $\mathrm{N}$ increase could be related to lignin compounds. Fioretto et al. [44] reported that most $\mathrm{N}$ concentration in litter is bonded with lignin compounds, and $\mathrm{N}$ release will take place when lignin decomposition happens. They also suggested that lignin structure covers cell wall proteins, which protect them from microbial degradation [44].

\subsection{Carbon/Nitrogen Ratio}

The nature of warm-season turfgrass decomposition is different than that of cool-season turfgrass [45]. Warm-season turfgrass contains a relatively high concentration of C,

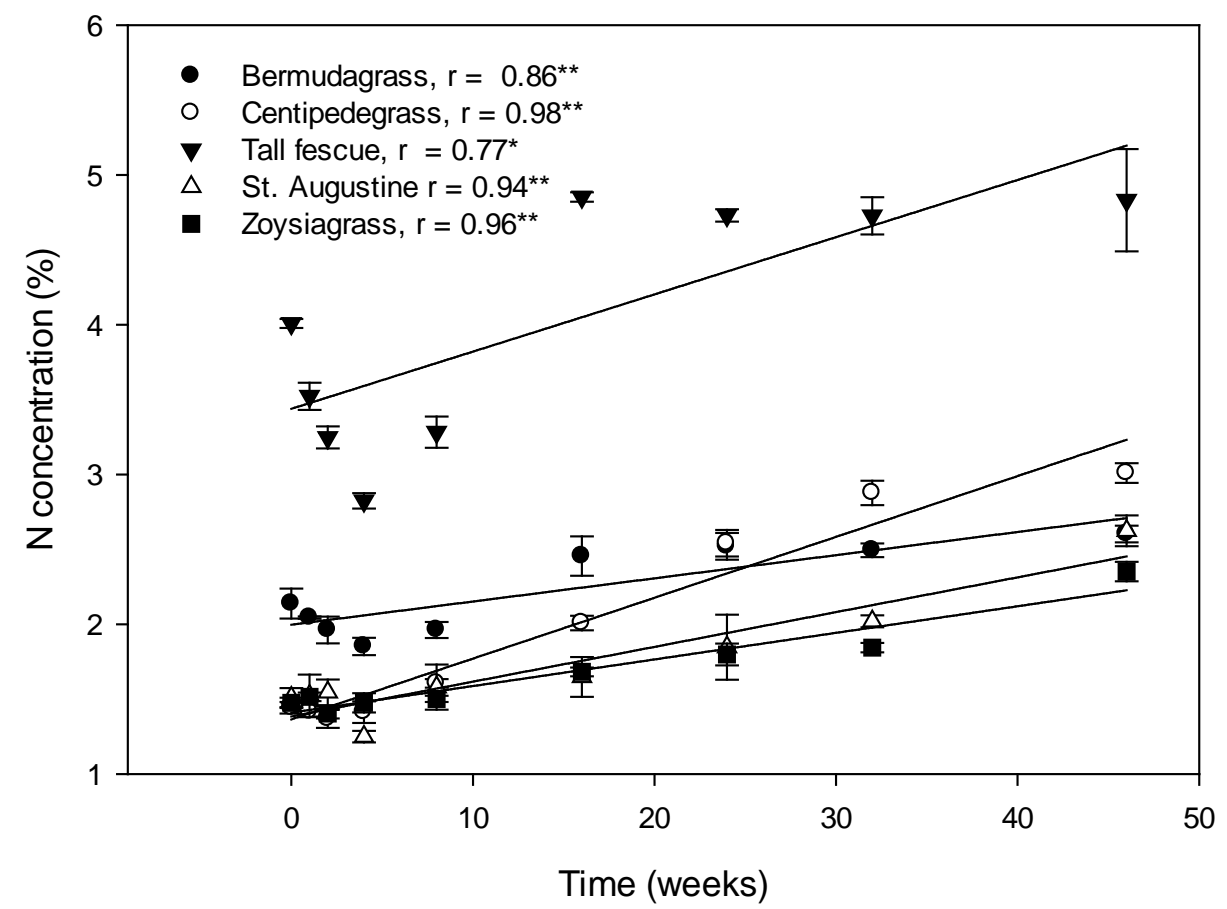

Figure 6. Relationship between $\mathrm{N}$ concentration (\%) and time of sampling for turfgrass clippings, Auburn University Turfgrass Research Unit, 2012-2013. Lines represent fitted curves for N\% content of each grass over time. 
allowing for slower initial decay [46]. Typically, initial C:N ratios were $18.6 \pm 0.7,28.7 \pm$ $1.0,10.3 \pm 0.1,22.4 \pm 1.3$ and $29.3 \pm 0.7$ for bermudagrass, centipedegrass, tall fescue, St. Augustinegrass, and zoysiagrass, respectively (Table 3). Table 3 illustrates C:N ratios of the turfgrass clippings. C:N ratios are typically used to describe a residue's propensity to immobilize or mineralize soil inorganic $\mathrm{N}$ [47]. The critical C:N ratio for immobilization/mineralization is between 19 and 30 [37] [48] [49]. Thus, the C:N ratio plays a major role on $\mathrm{N}$ dynamics in soil [50] [51].

During the first 4 weeks the C:N ratio increased for all turfgrass species but does not limit the activity of decomposer organisms ( $\mathrm{C}: \mathrm{N}$ ratio $<30: 1$, [26]. For example, the $\mathrm{C}: \mathrm{N}$ ratios of centipedegrass and zoysiagrass had increases for the first 2 weeks indicating a faster decay. Thereafter the $\mathrm{C}: \mathrm{N}$ ratio declined indicating stabilization of decay process. After 46 week the C:N ratio of tall fescue was 9.6, compared to 13.4, 14.3, 15.0, and 20.5 for St. Augustinegrass, bermudagrass, centipedegrass, and zoysiagrass, respectively. Throughout the study tall fescue had the lowest C:N ratio, averaging 10.9, indicating that clippings from this turfgrass would be a long-term $\mathrm{N}$ contributor. Other grasses had higher initial C:N ratios, and they could be responsible for soil $\mathrm{N}$ immobilization. For example, in the first 8 weeks average C:N ratios in centipedegrass, St. Augustinegrass and zoysiagrass were 28.7, 22.2 and 29.0, respectively. Similar conclusions were drawn by [26].

\subsection{Lignin/Nitrogen Ratio}

Warm season turfgrasses had higher lignin: $N$ ratio contents than tall fescue. Initial lignin: $N$ ratios were: $0.33,0.27,0.99,0.40$ and 0.08 for bermudagrass, centipedegrass, St. Augustinegrass, zoysiagrass, and tall fescue, respectively. Lignin:N ratios of warm season turfgrasses are comparable with that measured for sub-tropical forest ecosystem litter [23]. The low lignin of tall fescue helps to explain the faster decomposition of tall fescue clippings compared to other turfgrasses. In addition to that, adequate soil moisture contents played a major role in decomposition process by increasing or decreasing the process. That may be related to its effect on soil microorganisms and arthropods. Similar conclusions were drawn by [8] [9] [10] [52].

\section{Conclusion}

Our research demonstrates important aspects of warm and cool season turfgrass decomposition, mainly that tall fescue is comprised mostly of a quickly decaying labile fraction. Labile and recalcitrant decomposable $\mathrm{C}$ and $\mathrm{N}$ are important for short- and long-term effects on available $\mathrm{N}$ concentration in soil. Modeling warm- and coolseason turfgrass decomposition may enable turfgrass researchers and professionals to more accurately choose the best grass for home owners. Our study concluded that, zoysiagrass may be a better choice for lower $\mathrm{N}$ fertilization requirements and higher $\mathrm{C}$ accumulation in soils followed by bermudagrass, centipedgrass, St. Augustinegrass, and tall fescue. In addition, our study clearly shows that the decomposition of different turfgrass clippings presents rapidly released $\mathrm{N}$ within the thatch layer of turfgrass. 
Thus, a portion of that $\mathrm{N}$ will be available to that turfgrass during growing season. Then, $\mathrm{N}$ fertilization should be reduced when clippings are returned to turfgrass lawns. Moreover, differences in clipping $\mathrm{C}$ released under our study can be assumed that a portion of remaining $\mathrm{C}$ in the thatch layer could be important factor in soil $\mathrm{C}$ sequestration under southeastern U.S. turfgrass species and reduce climate change effect on turfed lawns [53]. However, further research is needed to determine the effect of returned clipping on the soil $\mathrm{C}$ and $\mathrm{N}$ balance of soil profile under different managements.

\section{References}

[1] Berg, B. and McClaugherty, C. (2008) Plant Litter: Decomposition, Humus Formation, Carbon Sequestration. Springer-Verlag Berlin Heidelberg, Germany.

http://dx.doi.org/10.1007/978-3-540-74923-3

[2] Swift, M.J., Heal, O.W. and Anderson, J.M. (1979) Decomposition in Terrestrial Ecosystems. Vol. 5, University of California Press, Berkeley, 266.

[3] Aerts, R. and Chapin III, F.S. (2000) The Mineral Nutrition of Wild Plants Revisited: A Reevaluation of Processes and Patterns. Advances in Ecological Research, 30, 1-67. http://dx.doi.org/10.1016/S0065-2504(08)60016-1

[4] Rovira, P. and Vallejo, V.R. (2007) Labile, Recalcitrant, and Inert Organic Matter in Mediterranean Forest Soils. Soil Biology and Biochemistry, 39, 202-213. http://dx.doi.org/10.1016/j.soilbio.2006.07.021

[5] Wardle, D.A., Bonner, K.I. and Barker, G.M. (2002) Linkage between Plant Litter Decomposition, Litter Quality, and Vegetation Responses to Herbivores. Functional Ecology, 16, 585-595. http://dx.doi.org/10.1046/j.1365-2435.2002.00659.x

[6] Adams, M.A. and Attiwill, P.M. (1986) Nutrient Cycling and Nitrogen Mineralization in Eucalyptus Forests of South-Eastern Australia. I. Nutrient Cycling and Nitrogen Turnover. Plant and Soil, 92, 319-339. http://dx.doi.org/10.1007/BF02372482

[7] Krauss, T.E.C., Zasoski, R.J., Dahlgren, R.A., Horwath, W.R. and Preston, C.M. (2004) Carbon and Nitrogen Dynamics in Forest Soil Amended with Purified Tannins from Different Plant Species. Soil Biology and Biochemistry, 36, 309-321. http://dx.doi.org/10.1016/j.soilbio.2003.10.006

[8] Hobbie, S. (1996) Temperature and Plant Species Control over Litter Decomposition in Alaskan Tundra. Ecological Monographs, 66, 503-522. http://dx.doi.org/10.2307/2963492

[9] Sterjiades, R. and Erikson, K.E. (1993) Biodegradation of Lignin. In: Scalbert, A., Ed., Polyphenolic Phenomena, INRA Editions, Paris, 115-126.

[10] Kitayama, K., Suzuki, S., Hori, M., Takyu, M., Aiba, S., Majalap-Lee, N. and Kikuzawa, K. (2004) On the Relationships between Leaf-Litter Lignin and Net Primary Productivity in Tropical Rain Forests. Oecologia, 140, 335-339. http://dx.doi.org/10.1007/s00442-004-1590-7

[11] Aerts, R. (1997) Climate, Leaf Litter Chemistry and Leaf Litter Decomposition in Terrestrial Ecosystems: A Triangular Relationship. Oikos, 79, 439-449. http://dx.doi.org/10.2307/3546886

[12] Vargas, D.N., Bertiller, M.B., Ares, J.O., Carrera, A.L. and Sain, C.L. (2006) Soil C and N Dynamics Induced by Leaf-Litter Decomposition of Shrubs and Perennial Grasses of the Patagonian Monte. Soil Biology and Biochemistry, 38, 2401-2410.

http://dx.doi.org/10.1016/j.soilbio.2006.03.006 
[13] Wieder, R.K. and Lang, G.E. (1982) A Critique of the Analytical Methods Used in Examining Decomposition Data Obtained from Litter Bags. Ecology, 63, 1636-1642. http://dx.doi.org/10.2307/1940104

[14] Selhorst, A. and Lal, R. (2013) Net Carbon Sequestration Potential and Emissions in Home Lawn Turfgrasses of the United States. Environmental Management, 51, 198-208. http://dx.doi.org/10.1007/s00267-012-9967-6

[15] Pandey, S.K., Singh, H. and Singh, J.H. (2014) Effect of Environmental Conditions on Decomposition in Eight Woody Species of a Dry Tropical Forest. Plant Biosystems, 148, 410418. http://dx.doi.org/10.1080/11263504.2013.772923

[16] Tripathi, G., Deora, R. and Singh, G. (2013) The Influence of Litter Quality and MicroHabitat on Litter Decomposition and Soil Properties in a Silvopasture System. Acta Oecologica, 50, 40-50. http://dx.doi.org/10.1016/j.actao.2013.01.013

[17] Cochran, V.L. (1991) Decomposition of Barley Straw in a Subarctic Soil in the Field. Biology and Fertility of Soils, 10, 227-232. http://dx.doi.org/10.1007/BF00337372

[18] Sluiter, A., Hames, B., Ruiz, R., Scarlata, C., Sluiter, J., Templeton, D. and Crocker, D. (2011) Determination of Structural Carbohydrates and Lignin in Biomass. National Renewable Energy Laboratory. Technical Report NREL/TP-510-42618.

[19] Stubbs, T.L., Kennedy, A.C., Reisenauer, P.E. and Burns, J.W. (2009) Chemical Composition of Residue from Cereal Crops and Cultivars in Dryland Ecosystems. Agronomy Journal, 101, 538-545. http://dx.doi.org/10.2134/agronj2008.0107x

[20] Hunt, H.W. (1977) A Simulation Model for Decomposition in Grasslands. Ecology, 58, 469-484. http://dx.doi.org/10.2307/1938998

[21] SAS Institute (2007) SAS System for Windows Release 9.1.3. SAS Institute, Cary, NC.

[22] Systat Software (2009) SigmaPlot 12.3. Systat Software, Inc., San Jose, CA.

[23] Laishram, I.D. and Yadava, P.S. (1988) Lignin and Nitrogen in the Decomposition of Leaf Litter in a Subtropical Forest Ecosystem at Shiroi Hills in North-Eastern India. Plant and Soil, 106, 59-64. http://dx.doi.org/10.1007/BF02371195

[24] Berg, B. (2000) Litter Decomposition and Organic Matter Turnover in Northern Forest Soils. Forest Ecology and Management, 133, 13-22. http://dx.doi.org/10.1016/S0378-1127(99)00294-7

[25] Devi, A.S. and Yadava, P.S. (2007) Wood and Leaf Litter Decomposition of Dipterocarpus tuberculatus Roxb in a Tropical Deciduous Forest of Manipur, Northeast India. Current Science, 93, 243-246.

[26] Kopp, K.L. and Guillard, K. (2004) Decomposition Rates and Nitrogen Release of Turf Grass Clippings. Proceedings of the 4th International Crop Science Congress, Brisbane, 26 September-1 October 2004.

http://www.cropscience.org.au/icsc2004/poster/2/5/2/860_koppk.htm

[27] Dang, C.K., Schindler, M., Chauvet, E. and Gessner, M.O. (2009) Temperature Oscillation Coupled with Fungal Community Shifts Can Modulate Warming Effects on Litter Decomposition. Ecology, 90, 122-131. http://dx.doi.org/10.1890/07-1974.1

[28] Fernandes, I., Uzun, B., Pascoal, C. and Cassio, F. (2009) Responses of Aquatic Fungal Communities on Leaf Litter to Temperature Change Events. International Review of Hydrobiology, 94, 410-418. http://dx.doi.org/10.1002/iroh.200811163

[29] Ferreira, V. and Chauvet, E. (2011) Synergistic Effects of Water Temperature and Dissolved Nutrients on Litter Decomposition and Associated Fungi. Global Change Biology, 17, 551564. 
[30] Ferreira, V. and Chauvet, E. (2011) Future Increase in Temperature More than Decrease in Litter Quality Can Affect Microbial Litter Decomposition in Streams. Oecologia, 167, 279291. http://dx.doi.org/10.1007/s00442-011-1976-2

[31] Geraldes, P., Pascoal, C. and Cassio, F. (2012) Effects of Increased Temperature and Aquatic Fungal Diversity on Litter Decomposition. Fungal Ecology, 5, 734-740.

http://dx.doi.org/10.1016/j.funeco.2012.05.007

[32] Hamido, S.A., Wood, C.W. and Guertal, E.A. (2016) Carbon Dioxide Flux from Bermudagrass Turf as Affected by Nitrogen Rate. Agronomy Journal, 108, 1000-1006.

[33] Fraser, L.H. and Hockin, A.D. (2013) Litter Decomposition Rates of Two Grass Species along a Semi-Arid Grassland-Forest Ecocline. Journal of Arid Environments, 88, 125-129. http://dx.doi.org/10.1016/j.jaridenv.2012.07.009

[34] Hamido, S.A., Wood, C.W. and Guertal, E.A. (2016) Nitrogen Fertilization of Bermudagrass Affects Carbon Dioxide Emissions. Golf Course Management, 5, 88-91.

[35] Wood, C.W. and Edwards, J.H. (1992) Agroecosystem Management Effects on Soil Carbon and Nitrogen. Agriculture, Ecosystems \& Environment, 39, 123-138.

[36] McCurdy, J.D., McElroy, J.S., Guertal, E.A. and Wood, C.W. (2013) Dynamics of White Clover Decomposition in a Southeastern Bermudagrass Lawn. Agronomy Journal, 105, 1277-1282.

[37] Aber, J.D. and Melillo, J.M. (1980) Litter Decomposition: Measuring Relative Contributions of Organic Matter and Nitrogen to Forest Soils. Canadian Journal of Botany, 58, 416-421.

[38] Blair, J.M. (1988) Nitrogen, Sulfur and Phosphorous Dynamics in Decomposing Deciduous Leaf Litter in the Southern Appalachians. Soil Biology and Biochemistry, 20, 693-701. http://dx.doi.org/10.1016/0038-0717(88)90154-X

[39] Gallardo, A. and Merino, J. (1992) Nitrogen Immobilization in Leaf Litter in Two Mediterranean Ecosystems of SW Spain. Biogeochemistry, 15, 213-228. http://dx.doi.org/10.1007/BF00002937

[40] Dutta, R.K. and Agrawal, M. (2001) Litterfall, Litter Decomposition and Nutrient Release in Five Exotic Plant Species Planted on Coal Mine Spoils. Pedobiologia, 45, 298-312. http://dx.doi.org/10.1078/0031-4056-00088

[41] Enoki, T. and Hawaguchi, H. (2000) Initial Nitrogen and Topographic Moisture Effects on the Decomposition of Pine Needles. Ecological Research, 15, 425-434. http://dx.doi.org/10.1046/j.1440-1703.2000.00363.x

[42] Guo, L.B. and Sims, R.E.H. (1999) Litter Decomposition and Nutrient Release via Litter Decomposition in New Zealand Eucalypt Short Rotation Forests. Agriculture, Ecosystems \& Environment, 75, 133-140. http://dx.doi.org/10.1016/S0167-8809(99)00069-9

[43] Rodriguez Pleguezueloa, C.R., Duran Zuazo, V.H., Muriel Fernandez, J.L., Martın Peinado, F.J. and Franco Tarifa, D. (2009) Litter Decomposition and Nitrogen Release in a Sloping Mediterranean Subtropical Agroecosystem on the Coast of Granada (SE, Spain): Effects of Floristic and Topographic Alteration on the Slope. Agriculture, Ecosystems \& Environment, 134, 79-88. http://dx.doi.org/10.1016/j.agee.2009.05.019

[44] Fioretto, A., Nardo, C.D., Papa, S. and Fuggi, A. (2005) Lignin and Cellulose Degradation and Nitrogen Dynamics during Decomposition of Three Leaf Litter Species in a Mediterranean Ecosystem. Soil Biology and Biochemistry, 37, 1083-1091.

http://dx.doi.org/10.1016/j.soilbio.2004.11.007

[45] USDA-NRCS (2004) Comparing Warm-Season and Cool-Season Grasses: For Erosion Control, Water Quality, and Wildlife Habitat.

http://teamhabitat.sjrcd.org/WSGMaryland.pdf 
[46] Fortes, C., Trivelin, P.C.O. and Vitti, A.C. (2012) Long-Term Decomposition of Sugarcane Harvest Residues in Sao Paulo State, Brazil. Biomass and Bioenergy, 42, 189-198. http://dx.doi.org/10.1016/j.biombioe.2012.03.011

[47] Hadas, A., Kautsky, L., Goek, M. and Kara, E.E. (2004) Rates of Decomposition of Plant Residues and Available Nitrogen in Soil, Related to Residue Composition through Simulation of Carbon and Nitrogen Turnover. Soil Biology and Biochemistry, 36, 255-266. http://dx.doi.org/10.1016/j.soilbio.2003.09.012

[48] Lutz, H.J. and Chandler, R.F. (1946) Forest Soils. John Wiley \& Sons Inc., New York.

[49] Edmonds, R.L. (1984) Long Term Decomposition and Nutrient Dynamics in Pacific Silver Fir Needles in Western Washington. Canadian Journal of Forest Research, 14, 395-400.

[50] Magid, J., Mueller, T., Jensen, L.S. and Nielsen, N.E. (1997) Modelling the Measurable: Interpretation of Field-Scale $\mathrm{CO}_{2}$ and N-Mineralization, Soil Microbial Biomass and Light Fractions as Indicators of Oilseed Rape, Maize and Barley Straw Decomposition. In: Cadisch, G. and Giller, K.E., Eds., Driven by Nature: Plant Litter Quality and Decomposition, CAB International, Wallingford, 349-362.

[51] Hadas, A., Doane, T.A., Kramer, A.W., van Kessel, C. and Horwath, W.R. (2002) Modelling the Turnover of ${ }^{15} \mathrm{~N}$ Labelled Fertilizer and Cover Crop in Soil and Its Recovery by Maize. European Journal of Soil Science, 53, 541-552. http://dx.doi.org/10.1046/j.1365-2389.2002.00483.x

[52] Tu, L.-H., Hu, H.-L., Hu, T.-X., Zhang, J., Li, X.-W., Liu, L., Xiao, Y.-L., Chen, G. and Li, R.-H. (2014) Litterfall, Litter Decomposition, and Nutrient Dynamics in Two Subtropical Bamboo Plantations of China. Pedosphere, 24, 84-97.

[53] Hamido, S.A., Wood, C.W. and Guertal, E.A. (2016) Carbon Sequestration under Warm Season Turfgrasses in Home Lawns. Journal of Geoscience and Environment Protection, 4, 53-63. http://dx.doi.org/10.4236/gep.2016.49005

\section{Submit or recommend next manuscript to SCIRP and we will provide best service for you:}

Accepting pre-submission inquiries through Email, Facebook, LinkedIn, Twitter, etc. A wide selection of journals (inclusive of 9 subjects, more than 200 journals)

Providing 24-hour high-quality service

User-friendly online submission system

Fair and swift peer-review system

Efficient typesetting and proofreading procedure

Display of the result of downloads and visits, as well as the number of cited articles Maximum dissemination of your research work

Submit your manuscript at: http://papersubmission.scirp.org/

Or contact ajcc@scirp.org 